\title{
General aspects of physalis cultivation
}

\author{
Aspectos gerais da cultura da physalis
}

\begin{abstract}
Janaína Muniz $^{{ }^{*}}$ Aike Anneliese Kretzschmar ${ }^{\mathrm{I}}$ Leo Rufato ${ }^{\mathrm{I}}$ Tânia Regina Pelizza ${ }^{\mathrm{I}}$ Andrea De Rossi RufatoII Tiago Afonso de Macedo ${ }^{I}$
\end{abstract}

\section{- REVIEW -}

\section{ABSTRACT}

The Physalis peruviana $L$. is an exotic fruit that belongs to the Solanaceae family with recent production in Brazil. This is presented as an alternative production with nutritional potential and economic value. The cape gooseberry plant has a high added value that can be used from its root to the fruit itself. The roots and leaves are rich in medicinal properties that are used in pharmacology. The fruit is sweet and have good content of vitamins $A, C$, iron, phosphorus and fiber, often used in making jellies, jams, juices and ice creams. To improve the plant canopy, but also contribute to the quality and appearance of the fruit produced some cultural practices such as staking, training systems, pruning and thinning are used. The aim of this review is to provide technical and scientific data about the culture of physalis.

Key words: small fruit, Solanaceae, Physalis peruviana, farming.

RESUMO

A Physalis peruviana L. é uma fruta exótica pertencente à família Solanaceae com produção recente no Brasil. Esta se apresenta como uma alternativa de produção com potencial valor nutricional e econômico. A planta da fisalis possui um alto valor agregado, podendo ser utilizada desde sua raiz até o fruto propriamente dito. As raízes e as folhas são ricas em propriedades medicinais que são utilizadas na farmacologia. O fruto é açucarado e com bom conteúdo de vitaminas A, C, ferro, fósforo e fibras, muito utilizado na fabricação de geleias, doces, sucos e sorvetes. Para melhorar o dossel vegetativo da planta, como também contribuir para a qualidade e aparência do fruto produzido, utiliza-se, durante seu cultivo, algumas práticas culturais, como tutoramento, condução, poda e desbrote. O objetivo desta revisão é fornecer dados técnico-científicos sobre a Cultura da Physalis.

Palavras-chave: pequenas frutas, solanácea, Physalis peruviana, cultivo.

\section{INTRODUCTION}

Despite Physalis has been conformed into the small-fruit trees group, it is a genus of plants in the nightshade family (Solanaceae). Solanaceae family has several species with great economic value as potato (Solanum tuberosum), eggplant (S. melongela), tomato (S. lycopersicum), cucumber (S. muricatum), peppers and green pepper (SOUZA \& LORENZI, 2005), besides species with pharmacological properties (Atropa belladonn and Hyocyamus niger) and ornamental species (Petunia hybrida and Brugmansia suaveolens).

Physalis started to have commercial importance in Colombia in 1985, where it has been widely introduced into cultivation and sold in natura and packed in markets (NOVOA et al., 2006). Nowadays, Colombia is the biggest world producer of Physalis followed by South Africa (CHAVES, 2006) and it is the second fruit in importance, corresponding to $54 \%$ of in natura fruit exportation. Probably, Colombia is the country with the larger area of Physalis cultivation, around 800 to 1000 hectares, producing between 15 to $28 \mathrm{t} \mathrm{ha}^{-1}$ (MIRANDA, 2004).

In Brazil, Physalis cultivation started in 1999 in Estação Experimental Santa Luzia (São Paulo, Brazil) which works until now (RUFATO, 2010), showing great results in soil diversity and spacing. From 2008, new fruit farmers started to cultivate Physalis, and this improvement has brought good perspectives and success for family farming

IUniversidade do Estado de Santa Catarina (UDESC), Centro de Ciências Agroveterinárias (CAV), 88520-000, Lages, SC, Brasil. E-mail: janainamuniz@gmail.com.*Autor para correspondência.

IIEmbrapa Uva e Vinho, Estação Experimental de Fruticultura Temperada, Vacaria, RS, Brasil. 
(MUNIZ et al., 2010). Even so, Physalis cultivation is still recent in Brazil, but it is expanding in Rio Grande do Sul State, mainly in Vacaria, Roca Sales and Áurea cities, as well in Santa Catarina State, in Fraiburgo, Urupema and Lages cities (LIMA et al., 2009).

Physalis (Physalis peruviana L.) produces a small and sweet fruit, rich in A and $C$ vitamins besides alkaloids, flavonoids, carotenoids and bioactive compounds considered functional ones (CHAVES, 2006). However, its fruit is considered exotic and expensive. Besides the fruit commercialization, it is possible to market its roots, leaves and the inflated papery calyx enclosing each berry, is extensively used in adornments (MUNIZ et al., 2010).

Considering the level of biogenetic oxidation, Physalis genus is the most developed in Solanaceae family. This important position is due to the presence of polyoxygenated metabolites, withasteroids, derived from ergostane. The enzymatic system in Physalis plants has the ability to oxidize the carbon atom from the steroid nucleus and side chain, exception to C-8, C-9 and C-11 carbons, originating a wide variety of chemical structures: physalins, withaphysalins, ixocarpalactones, acnistines, among others. Solanaceae are characterized by the predominance of withasteroids, being Physalis the most important among the twelve genera (TOMASSINI et al., 2000). Recent studies with extracts of Physalis leaves have demonstrated important biological activities, as antifungal, antioxidant, antitumoral, anti-inflammatory, molluscicide and insect repellent, due to bioactive compounds as whitanolides, phenols and ethanolics (FRANCO et al., 2007; QUISPE et al., 2009; FANG et al., 2011).

Physiology and Botany

The first description of Physalis genus was made by Linnaeus in 1753. According to "Plants Database", from United States Department of Agriculture (USDA, 2012), the taxonomic classification of Physalis is: Kingdom Plantae; Subkingdom, Tracheobionta; Superdivision, Spermatophyta; Division, Magnoliophyta; Class, Magnoliopsida; Subclass, Asteridae; Order, Solanales; Family, Solanaceae; Genus, Physalis L.; Species, peruviana.

\section{Physalis peruviana L.}

Probably, this specie is native from South America Andes, mainly Peru, Colombia and Ecuador (MEDINA, 1991). It easily adapts in huge climatic conditions and can be producing in the same place for years. In Colombia, there are plants more than 20 years-old in protected tillage. It is a perennial, shrubby and branched plant, with indeterminate growth habit; without training, it can grow around 1.0 to 1.5 meters; however, with training it can exceed 2.0 meters high (FISCHER, 2000).

Reticular system is branched (10 to 15 centimeters), deep and fibrous, with the main roots between 50 to $80 \mathrm{~cm}$ (ANGULO, 2005).The main stem is herbaceous, green and composed by 8 to 12 nodes, giving origin to productive ramifications by dichotomy. Each node gives origin to two buds, one vegetative and, the other one, flowering (LAGOS, 2006).

Leaves are simple, heart-shaped and alternated, 5 to 15 centimeters long and 4 to 10 centimeters wide (FISCHER, 2000). Flowers are unique, pedunculate and hermaphrodite, derived from the axillary bud, with five yellow petals. Calyx is green, formed by five sepals around 5 centimeters long, covering completely the fruit during all its development. When the fruit is ripened, calyx shows a brown color which is an indicator to be observed for determining the point of harvest (ÁVILA et al., 2006).

The fruit is berry-shaped, like a small globe, from green to yellowish, with a diameter around 12.5 to 25.0 millimeter and a weight from 4 to $10 \mathrm{~g}$, containing 100 to 300 seeds. Physalis fruits show high level of ascorbic acid (36mg $100 \mathrm{~g}^{-1}$ pulp), rich in Vitamin A (1730 UI. $100 \mathrm{~g}^{-1}$ of pulp), iron (38mg $100 \mathrm{~g}^{-1}$ of pulp) and phosphorus (1.2 mg $100 \mathrm{~g}^{-1}$ of pulp) (FISCHER, 2000). The fruit is small round, bright orange and sweet when ripe, making it ideal to eat in natura or in pies and jams. Seeds are numerous and germinate easily in soils with relative humidity, this way justifying its growing away from the cultivation areas (SOARES et al., 2009).

Soil and climatic conditions for cultivation

In order to introduce a species in a peculiar area, it is needed to do an evaluation of weather and soil conditions, aiming to help species selection for a better adaptation (RUFATO et al., 2008).

Physalis can develop in a huge range of soil and climatic conditions and it is classified as a very tolerant species due to its adaptability to Mediterranean climates and to several soil types (FISCHER, 2000). Farm producers of Physalis, in Colombia, are equally similar to farm producers from cold tempered climate regions (RUFATO et al., 2008).

Altitude has strong influence on Physalis plants and fruits. An increase of ultraviolet radiation and an decrease in the air temperature with increasing altitude, this way resulting in smaller plants, small and thick leaves, which delays the peak output. In 
Colombia, Physalis is cultivated in high altitudes from 2000 to 2650 meters high (FISCHER, et al., 2005). In Brazil, Physalis has good adaptation to the wide soil and climate conditions, being that excessive humidity, drought, cold and heat prejudice growing and development of the plants, as well the final quality of the product and decreasing productivity (MUNIZ et al., 2011).

As for the soil type, the ideal for cropping is sandy-clayey, good drainage, grained soil, preferentially those ones rich in organic material (greater than 4\%) and $\mathrm{pH}$ between 5.5 and 6.8 (FISCHER et al., 2005). It is important to avoid waterlogged soil and those that, previously, were cultivated with other species of Solanaceae (RUFATO et al., 2008).

As for solar orientation, researches made until now were not conclusive for Physalis, but that it should be given priority to north-south expositions propitiating a better exploitation of solar energy in the photosynthetic process of the plants. In order to obtain a fruit with quality, Physalis needs around 1500 to 2000 hours of light a year (RUFATO et al., 2008).

According to FISCHER (2000), Physalis shows better growing and development in regions with annual temperatures between 13 to $18^{\circ} \mathrm{C}$. For ANGULO (2005), the optimal temperature is between 8 to $20^{\circ} \mathrm{C}$. However, MIRANDA (2004) stated the favorable temperature for growing and development of the plants is $18^{\circ} \mathrm{C}$. SALAZAR (2006) found that $6.3^{\circ} \mathrm{C}$ is the physiologic-base temperature for Physalis growing. High temperatures (higher than $30{ }^{\circ} \mathrm{C}$ ) damage flowering and fruiting stages, promoting early ageing (ANGULO, 2005). However, heat does not obstruct fruits production, as evidenced in Hawai, where plants produce fruits with diurnal temperatures around 27 to $30^{\circ} \mathrm{C}$. Low temperatures (nocturnal lower than $10^{\circ} \mathrm{C}$ ) can obstruct the plant growing (RUFATO et al., 2008). Temperature and light have an important role in relation to size, color, nutritional content, taste and fruits ripening stage (RUFATO, 2010). The occurrence of late frosts, mainly on the higher regions of Santa Catarina and Rio Grande do Sul, Brazil, can cause significant damages to production. Physalis tolerates light frosts, but shows serious problems when nocturnal temperatures are lower than $-2^{\circ} \mathrm{C}$ (RUFATO et al., 2008).

Rainwater should range between 1000 to 1800 millimeter and the average relative humidity from 70 to $80 \%$ is ideal during the growing season (POPOVA et al., 2010). Water demand at least 800 millimeter during growing period. Excess moisture can benefit diseases, prejudice pollination and cause yellowing and leaves fall (RUFATO et al., 2008).

Physalis is very susceptible to drought and strong winds, so, its cultivation should be protected by windbreaks (RUFATO et al., 2008).

\section{Plant propagation}

Plants multiplication has been practiced for millenniums, since primitive man abandoned a nomadic life and settled on a region to produce his own food. The propagation methods of Physalis are sexual reproduction, through seeds utilization, and asexual method, using in vitro cultivation and grafting. Plant propagation through seeds can be defined as the natural way in which plants are reproduced in its native environment or in an artificial one as a result of man-induced intervention. Commercially, the most used way for Physalis propagation is sexual. Seeds emergence depend on the physiological and biochemical characteristics, their relation with the environment and the efficient use of their supply during germination. In order to the seeds propagation be successful, it is needed to consider humidity, temperature, light and oxygen, which together are essential factors to have a normal process. In the absence of any of these factors to germination of seed will not happen.

Physalis seeds have a high germination percentage, around 85 to $90 \%$ and they germinate from 10 to 15 days (FISCHER et al., 2005). For RUFATO et al. (2008), sometimes germination is erratic and germination rate can be insignificant. It seems that Physalis seeds germinate more easily when in temperatures between 7 to $13^{\circ} \mathrm{C}$ at night and between 22 to $28^{\circ} \mathrm{C}$ during the day.

For seeds extraction, firstly the fruits are liquefied in low velocity and left to leaven during 48 hours in a glass container; after that, the seeds are washed in water, and left to dry in the shade on an absorbent paper (FISCHER, 1995; MIRANDA, 2004). However, RUFATO et al. (2008) described that leaven process is not needed for Physalis. Once the seeds are extracted, it is important to leave them on rest, during at least two weeks, because if sowing was made immediately, seeds will take time to germinate. After extraction, seeds can be stocked at room temperature for until two years. Seeds storage can be done in permeable packs (paper packs) and semi-permeable packs (plastic bags), provided that they are maintained in temperatures between 5 to $10^{\circ} \mathrm{C}$; or even, in airtight containers (sealed glass jar), independently of the temperature. However, stored seeds should be completely dried, because 
humidity interferes negatively on germination rate (RUFATO et al., 2008). For preventing diseases in sexual propagation seedlings as, for example, Cladosporium, Phoma, Alternaria, Phytium, Botrytis and Colletotrichum, it is recommended to disinfect their seeds with fungicides before sowing (ANGULO, 2005).

Tillage

For fruit growing, tillage, specie or variety and training system are important matters which affect productivity, quality, economy and profitability of the producer. Soil preparation aims to enhance its chemical and physical conditions in order to facilitate tillage. It is better to take time and resources for a good soil preparation than take corrective action later.

Among other factors, soil management practices should be taken in to consideration: crop, its root system and if it is a perennial or annual plant. How Physalis, in the south of Brazil, is considered perennial, the crop area is selected 4 to 5 months before planting. When defining the crop area, samples should be taken for analysis in order to know its chemical conditions and correction, if necessary, according to the crop requirements. It must be preferred areas where native solanaceous or plants from the same family had not been cultivated, due to the risk of fungi and bacteria in the soil (MUNIZ et al., 2010). The area must have a large amount of sunlight, not subject to strong winds and accumulation of cold air and humidity. So, it should be avoid pruning in soils showing flooding, because Physalis plant is sensible to high humidity and adapts better to well-drained and clayey soil (RUFATO et al., 2008). It is worth pointing out that an area with little declivity facilitates mechanization it is less susceptible to erosion.

Planting

Decisions taken at the moment of planting are very important, because they have a great influence on the yield of the Physalis crop. The pruning time is defined as a set of environmental factors reacting among them and interacting with the plant, promoting variation in crop yield. The stated Physalis cultivation can be done during all year. However, in Brazil there are no scientific researches certifying this information (LIMA et al., 2008).

According to MUNIZ et al. (2011), in Brazil, Physalis cultivation can be made in several periods of the year, depending on the region and climate. In subtropical regions, where there is no frost occurrence, it is possible to plant Physalis in any period of the year, being the crop cycle extended for until two years; after this period, productivity and quality of the fruits decreases. For climate in the south of Brazil, planting is recommended in the middle of October and November, due to low temperatures in the winter, becoming an annual crop cycle.

Physalis plants must be pruned with initial diameter above 0.50 centimeter and when reaching around 20 centimeter and showing two leaves (ANGULO, 2005). RUFATO et al. (2008) suggest that seedling pruning will be done when the plant reaches from 15 to 20 centimeter high and has three to four leaves. In this period, attention to water profiles needs to be intense, so, it is important to adopt an irrigation system (mainly drip method). Preferentially, planting should be done in rainy or cloudy days, in order to avoid dehydration of the plants. During the planting, it is advisable to add organic fertilizer completely mature (2 to $4 \mathrm{~kg}$ ), chemical fertilizer and correctives according to the soil analysis (FISCHER, 1995; MIRANDA, 2004).

\section{Fertilization and nutrition of the plants}

Fertilization is an agricultural practice consisting on the supply of fertilizers and manure on the soil, in order to reclaim or conserve its fertility, supplying the lack of nutrients and affording the crop development (RUFATO et al., 2009).

This practice is made mainly on the basis of research results in other countries. However, there are similar characteristics, as soil and climate types, in the main cultivation regions of Physalis in Colombia, Brazil and in the places where researches were done. But, it indicates that recommendations based on the same criteria can generate unsatisfactory results on nutritional aspects, ending up in less productivity and low quality. There is still no recommendation of specific fertilization for Physalis in Brazil, being it made on the basis of the recommendation to tomato tree crop (MUNIZ et al., 2011).

For Physalis, in the Colombian conditions, the most important nutrients are nitrogen, potassium, calcium and boron. Nitrogen is considered the most important macro-element, responsible by longitudinal growing of the branches and fruit production. Application must be 1 to $2 \mathrm{~kg}$ of poultry litter in sowing and from 100 to $150 \mathrm{~g}$ (10-30-10 or triple superphosphate) in each 3 to 4 months. Potassium is responsible by flowering and fruits fixation. Its application should be made before flowering $\left(\mathrm{KNO}_{3}\right.$ or $\mathrm{K}_{2} \mathrm{SO}_{4}$ ). Calcium is very important in tissues and calyx formation. Boron is the most required micronutrient by the plants and its deficiency reduces the content of soluble solids of the fruit (ANGULO, 2005). 
Crop handling

Physalis cultivation is considered very simple and the most part of its handling is still made according to techniques used for tomato tree cultivation (CHAVES, 2006). Among the best agricultural practices, in Physalis crop can be detached fertilization, insects and diseases control and crop harvest (RUFATO et al., 2009).

Using some agricultural practices as fertilization, training, pruning and sprouting, it is possible to improve the plant canopy as well to contribute on quality and appearance of the fruit (MUNIZ et al., 2010). With proper and planned handling, the plant can produce for until two years in the south of Brazil. However, from the second year, there is a reduction on productivity and on the quality of the fruits (RUFATO et al., 2009).

Irrigation management can be monitored through visual observation or with specific equipments. Drip irrigation must be guaranteed in the first days after pruning, avoiding plants drying (FISCHER, 1995; MIRANDA, 2004). CAMPOS (2000) sets the technical basis to irrigation management of Physalis from the necessity of irrigation, through the balance between evapotranspiration and precipitation. That recommendation consists in periodic irrigation, requiring 2 to 6 liters per plant a day, for Colombian conditions.

Because Physalis can form a dense ramification and its branches are recumbent, it requires support. So, training system is mandatory and the row spacing adopted needs to be in agreement with the used pruning regime. Required training system is chosen according to sowing density, local topography, material costs and their availability (LIMA et al., 2009). According to MIRANDA (2005), Physalis commercial planting, in Colombia, is planned with plants training system. Although it represents an initial increase in the cost of production, training system is an advantageous practice, because it benefits phytosanitary control, facilitates some tillage handling and upgrades the quality of the fruit. MARTÍNEZ et al. (2008) added there is not a training system which attends the needs to Physalis crop yet, but the ones which can be applied are described for others fruit trees production, as for example, tomato tree crop (RUFATO et al., 2008). However, training systems used for Physalis crop are similar, but not equal to those applied on tomato tree crop; in this case, for each training system used there is a different handling (MUNIZ et al., 2010). In general, limitations in using a specific type of training system are related to the excessive utilization of wood (stakes, brackets) and the high value of wire (MIRANDA, 2005). In Brazil, the main training systems for Physalis are the free-standing espalier method, d "in X" method, and “in V” method (RUFATO et al., 2008).

Planting distance has variation according to the applied training system, and the distance between plants from 0.50 to 1.50 meters. In general, the recommended planting distance is $1.00 \times 3.00$ or 0.50 x $3.00 \mathrm{~m}$ among plants and among rows, respectively. However, the local topography is the most important aspect influencing the definition of the row spacing, because it has a crucial role on aeration, humidity and tillage handling (RUFATO et al., 2008). When in flat lands, it is advisable more approximated distances, but in slope areas the row spacing should be increased (FISCHER, 1995; MIRANDA, 2004).

According to VILLEGAS (2009), Physalis pruning is one of the most recommended practices due to its influence on the fruit size, on the improvement of the plant architecture and its effectiveness on training system. MIRANDA (2004) defined pruning as the handling which modifies plant growing habit, improving its architecture in order to capture solar radiation and, as consequence, greater efficiency on photosynthetic processes. MIRANDA (2004) mentioned four kinds of pruning: formation pruning, that is thinning the main stem around 15 to 20 centimeter high and the sprouts elimination; maintenance pruning, in order to eliminate longer, non-productive branches (or in a bad position); sanitary pruning, to remove branches with diseases or pests; and renovation pruning, in order to renew the crop from the "stump" of the old plants. For VILLEGAS (2009) formation pruning is the elimination of sprouts from the base of the plant on the first $40 \mathrm{~cm}$ high in order to reduce the relative humidity of the crop.

Crop must be inspected diary, in order to verify the occurrence of pests or diseases and, this way, to adopt a more adequate control method. The main insects identified on Physalis crop are, most of the time, those reported to the other species of Solanaceae family. Its control just must be done when there is economical injury, but, periodic spraying with natural extracts can be made (LIMA et al., 2008), biological insecticides and repellents (RUFATO et al., 2008). FISCHER et al. (2005) cited the main pests which attack Physalis crop in Colombian regions and divided them as soil, leaves and fruit pests. Soil pests are Spodoptera sp., Agrotis sp., and Feltia sp. Leaves pests are Liriomyza sp. (leaf miner fly), Epitrix cucumeris (potato flea beetle), Aphys sp., Myzus sp. (aphids), Frankliniella sp. (trips) and Trialeurodes 
vaporariorum (greenhouse whitefly). Pests which attack fruit are Aculops sp. (acarids), Heliothis sp. (heliothis moth). Most of the pests in Brazil are from Hemiptera and Lepidoptera orders. Nowadays, there is not still a range of authorized insecticides to be utilized in Physalis crop, so, the most used way for pest control is the integrated pest management (IPM) with the use of adequate cultivation practices and natural biological control (MUNIZ et al., 2010).

With the Physalis exportation increasing in Colombia, the cultivated area has increased as well and this monoculture system has brought, as consequence, the incidence and severity growing of diseases which, during many years, were equilibrated. Limiting diseases of $\boldsymbol{P h y s a l i s}$ harvest and postharvest have several origins and are caused by fungi, bacteria, viruses, nematodes and phytoplasmas, but diseases caused by fungi are more abundant. Handling strategies for those diseases are related to good agricultural cropping practices, from the selection of seed with good quality to the right choice of fungicides (MUNIZ et al., 2010).

\section{Harvest and postharvest}

There are several methods to define the most appropriated period to make Physalis harvest, however, calyx coloration is the most used characteristic by farm producers and traders. Meantime, this parameter generates doubts, besides it does not make possible the knowledge of the physical fruit characteristics. The fruit calyx, besides being an indicator to harvest determination, it extends the postharvest life of the fruit until 2/3 (ÁVILA et al., 2006). Calyx still has the role of protecting the fruit naturally, so, it is necessary to avoid its detachment in order to increase the possibilities of storage during longer periods (RUFATO et al., 2008).

As other species of small fruits, Physalis is a climacteric fruit (RUFATO et al., 2008) and shows a long harvest time (MUNIZ et al., 2011). When the harvest starts, it should be performed weekly and without interruption (RUFATO et al., 2008). In the Mountainous Area of Santa Catarina, Brazil, Physalis harvest is made one to three times a week, depending on the stage of the plant and production level (MUNIZ et al., 2010). Harvest should be done with mild temperature and avoiding harvest during rainy periods. Injured fruits due to pests or diseases should be discarded. The most appropriated way to collect fruits is handmade and, preferentially, with the use of scissors (RUFATO et al., 2008).

For FISCHER et al. (2005), the duration of Physalis harvest time in Colombia is around six months. However, in the Mountainous Area of Santa Catarina, Brazil, the harvest time is extended until the first frosts that occur in that region (RUFATO et al., 2008), during around four months (MUNIZ et al., 2010).

In postharvest handling, it is important to pay attention on the aspects like color, firmness and organoleptic characteristics. Each stage of postharvest handling involves time and inflicts stress to horticultural products. Main stresses are mechanical injuries like wounds, cracks, compressions and impacts, so reducing drastically the quality of the fruit, influencing its chemical and physical characteristics, besides propitiating contamination by fungi and bacteria.

Padronization, classification, packing and Physalis presentation are standardized by The Colombian Technic (Colombian Technical Standard) - NTC 4580, from Colombian Institute of Technical Standards (ICONTEC, 1999). This standard establishes the basic requirements for Physalis commercialization, as for in natura consumption, as for fruit procession (RUFATO et al., 2008).

\section{REFERENCES}

ANGULO, R. Uchuva el cultivo. Bogotá: Universidad de Bogotá Jorge Tadeo Lozano, Colciencias, Centro de Investigaciones y Asesorías Agroindustriales, 2005. 78 p.

ÁVILA, A.J. et al. Influencia de la madurez del fruto y del secado del cáliz en uchuva (Physalis peruviana L.), almacenada a $18^{\circ} \mathrm{C}$. Acta Agronómica Colombiana, Palmira, v. 55, n. 4, p. 29-38, 2006. Disponível em: <http://digital.unal.edu.co/ index. php/acta_agronomica/article/viewFile/477/820>. Acesso em: 13 jun. 2013

CAMPOS, A. Manejo del riego. In:___. Producción, poscosecha y exportación de la uchuva (Physalis peruviana L.). Bogotá: Unibiblos, Universidad Nacional de Colombia, 2000. p. 51-56.

CHAVES, A.C. Propagação e avaliação fenológica de Physalis sp. na região de Pelotas, RS. 2006. 65 f. Tese (Doutorado em Ciências - Fruticultura de Clima Temperado) - Universidade Federal de Pelotas, Pelotas, RS.

FANG, S.T. et al. Ten new withanolides from Physalis peruviana. Steroids. ed. 1-2, v. 77, p. 36-44, 2011. Disponível em: <http://www. mycochem.cn/Article/UploadFiles/201202/2012020313493525. pdf $>$. Acesso em: 23 mai. 2013. doi:10.1016/j.steroids.2011.09.011.

FISCHER, G. Crecimiento y desarrollo. In: __. Producción, poscosecha y exportación de la uchuva (Physalis peruviana L.). Unibiblos: Universidad Nacional de Colombia, 2000. p. 9-26.

FISCHER, G. Effect of root zone temperature and tropical altitude on the growth, development and fruit quality of cape gooseberry (Physalis peruviana L.). 1995. $171 \mathrm{f}$. Thesis (Faculty of Agriculture and Horticulture), Humboldt Universität zu Berlin, Berlin. 
FISCHER, G. et al. Avances en cultivo, poscosecha y exportación de la uchuva $\boldsymbol{P}$ peruviana $\mathbf{L}$. en Colombia. Bogotá: Universidad Nacional de Colombia, Faculdad de Agronomía, 2005. 222 p.

FRANCO, L.A. et al. Actividad antinflamatoria de extractos y fracciones obtenidas de cálices de Physalis peruviana L. Biomédica, Bogotá, v. 27, n. 1, p. 110-115, 2007. Disponível em: <http://www.revistabiomedica.org/index.php/biomedica/article/ viewFile/237/222>. Acesso em: 25 mai. 2013.

LAGOS, T.C. Biología reproductiva, citogenética, diversidad genética y heterosis en parentales de uvilla o uchuva Physalis peruviana L. 2006. 129 f. Tesis (Doctorado en Genética y Mejoramiento de Plantas) - Facultad de Ciencias Agropecuarias, Universidad Nacional de Colombia, Palmira.

LIMA, C.S.M. et al. Principais coeficientes técnicos e insumos envolvidos na implantação de physalis na região sul (RS). Revista Ceres, Viçosa, v. 56, n. 5, p. 555-561, 2009.

LIMA, C.S.M. et al. Caracterização química de frutas de physalis em relação a coloração do cálice. In: CONGRESSO BRASILEIRO DE FRUTICULTURA, 20., 2008, Vitória, ES. Anais... Vitória: SBF/UFES, 2008. 1 CD-ROOM.

MARTÍNEZ, F.E. et al. Efecto de la deficiencia de N, P, K, Ca, Mg y B en componentes de producción y calidad de la uchuva (Physalis peruviana L.). Agronomía Colombiana, Bogotá, v. 26, n. 3, p. 389-398, 2008. Disponível em: <http://www.nutricaodeplantas. agr.br/site/downloads/unesp_jaboticabal/omissao_physalis1.pdf $>$. Acesso em: 25 mai. 2013.

MEDINA, E. El cultivo de la uchuva tipo exportación. Revista Agricultura Tropical, Palmira, v. 28, n. 2, p. 55-58, 1991.

MIRANDA, D. Criterios para el establecimiento, los sistemas de cultivo, el tutorado y la poda de la uchuva. In: __. Avances en cultivo, poscosecha y exportación de la uchuva Physalis peruviana L. en Colombia. Bogotá: Universidad Nacional de Colombia, Faculdad de Agronomía, 2005. p. 29-54.

MIRANDA, D. Informes de visitas de asesoría técnica a fincas produtoras de uchuva (Physalis peruviana L.) en la Sabana de Bogotá y Antioquia. Bogotá: Facultad de Agronomía, Universidad Nacional de Colombia, 2004. 35 p.

MUNIZ, J. et al. Cultivo de Physalis peruviana L.: uma nova alternativa para pequenos produtores. Jornal da Fruta, Lages, Ano XVIII, n. 228, p. 22, 2010.

MUNIZ, J. et al. Sistemas de condução para o cultivo de physalis no Planalto Catarinense. Revista Brasileira de Fruticultura, Jaboticabal, v. 33, n. 3. p. 830-838, 2011.

NOVOA, R.M. et al. La madurez del fruto y el secado del cáliz influyen en el comportamiento poscosecha de la uchuva (Physalis peruviana L.) almacenada. Agronomía Colombiana, Bogotá, v. 24, n. 1, p. 77-86, 2006. Disponível em: <http://www.revistas.unal.
edu.co/index.php/agrocol/article/viewFile/20007/21142>. Acesso em: 12 dez. 2013.

POPOVA, A. et al. Evaluation of the development of Cape Gooseberry (Physalis peruviana L.) plant under the environmental conditions of South Bulgaria. In: BALWOIS, 2010, Ohrid, Anais... Ohrid, Republic of Macedonia, 2010. p. 1-10. Disponível em: $<$ http://balwois.com/balwois/administration/full_paper/ffp-1336. pdf>. Acesso em: 18 jul. 2012.

QUISPE, A. et al. Actividad citotóxica de Physalis peruviana (aguaymanto) en cultivos celulares de adenocarcinoma colorectal, próstata y leucemia mieloide crónica. Revista de Gastroenterología del Peru, Peru, v. 29, n. 3, p. 239-246, 2009. Disponível em: <http://sisbib.unmsm.edu.pe/BVRevistas/gastro/ vol29n3/pdf/a06v29n3.pdf>. Acesso em: 10 out. 2013.

RUFATO, A. De. R. Sistemas de condução, poda, pragas e doenças da cultura da physalis. In: MINI-CURSO DE PEQUENOS FRUTOS, SEMINÁRIO NACIONAL SOBRE FRUTICULTURA DE CLIMA TEMPERADO, 9., 2010, São Joaquim, SC. Anais... Lages: CAV/UDESC; São Joaquim: EPAGRI, 2010. p. 26-36.

RUFATO, L. et al. Sistemas de adubação, controle de insetos e doenças e atividades de colheita de physalis no Sul do Brasil. In: REUNIÃO TÉCNICA DA CULTURA DA PHYSALIS, 2009, Pelotas, RS. Anais... Pelotas: Fruticultura de Clima Temperado FAEM/UFPel, 2009. p. 23-31.

RUFATO, L. et al. Aspectos técnicos da cultura da physalis. Lages: CAV/UDESC; Pelotas: UFPel, 2008.100 p.

SALAZAR, M.R. Un modelo simple de producción potencial de uchuva (Physalis peruviana L.). 2006. 108 f. Tesis (Doctorado en Ciencias Agropecuarias Área Agraria) - Facultad de Agronomía, Escuela de Posgrados, Universidad Nacional de Colombia, Bogotá.

SOARES, E.L.C. et al. Gênero Physalis L. (Solanaceae) no Rio Grande do Sul, Brasil. Pesquisas, Botânica. São Leopoldo: Instituto Anchietano de Pesquisas, 2009. n. 60, p. 323-340. Disponível em: <http://www. anchietano.unisinos.br/publicacoes/botanica/ botanica60/artigo5.pdf> . Acesso em: 05 out. 2013.

SOUZA, V.C.; LORENZI, H. Botânica sistemática: guia ilustrado para identificação das famílias de Angiospermas da flora brasileira, baseado em APG II. Nova Odessa, SP: Instituto Plantarum, 2005. 640 p.

TOMASSINI, T.C.B. et al. Gênero Physalis - Uma revisão sobre vitaesteróides. Química Nova, São Paulo, v. 23, n. 1, p. 47-57, 2000. Disponível em: <http:/www.scielo.br/scielo.php?pid=S010040422 000000100011\%094\&script=sci_arttext>. Acesso em: 10 nov. 2013.

USDA, NRCS. The plants database. Greensboro:National Plant Data Team, (2012). NC 27401-4901 USA. Disponível em: http:// plants.usda.gov. Acesso em: 23 jul. 2013.

VILLEGAS, C.I. El cultivo de la uchuva (Physalis peruviana). San José, Costa Rica, 2009. p. 1-5. 